\title{
Do suspended sediment and bedload move progressively from the summit to the sea along Magela Creek, northern Australia?
}

\author{
WAYNE D. ERSKINE ${ }^{1,2,3}$, MICHAEL J. SAYNOR ${ }^{1}$, KATE TURNER ${ }^{1}$, \\ TIMOTHY WHITESIDE ${ }^{4}$, JAMES BOYDEN ${ }^{1}$ \& KENNETH G. EVANS ${ }^{5}$ \\ 1 Hydrological, Geomorphological and Chemical Processes Group, Environmental Research Institute of the Supervising \\ Scientist, GPO 461, Darwin NT 0801, Australia \\ wde059@gmail.com \\ 2 School of Environmental \& Life Sciences, The University of Newcastle, PO Box 127, Ourimbah NSW 2258, Australia \\ 3 Research Institute for the Environment and Livelihoods, Charles Darwin University NT 0909, Australia \\ 4 Revegetation and Landscape Ecology Group, Environmental Research Institute of the Supervising Scientist, GPO 461, \\ Darwin NT 0801, Australia \\ 5 Mining Technology Group, School of Engineering \& Information Technology, Charles Darwin University, Darwin NT \\ 0909, Australia
}

\begin{abstract}
Soil erosion rates on plots of waste rock at Ranger uranium mine and basin sediment yields have been measured for over 30 years in Magela Creek in northern Australia. Soil erosion rates on chlorite schist waste rock are higher than for mica schist and weathering is also much faster. Sediment yields are low but are further reduced by sediment trapping effects of flood plains, floodouts, billabongs and extensive wetlands. Suspended sediment yields exceed bedload yields in this deeply weathered, tropical landscape, but the amount of sand transported greatly exceeds that of silt and clay. Nevertheless, sand is totally stored above the topographic base level. Longitudinal continuity of sediment transport is not maintained. As a result, suspended sediment and bedload do not move progressively from the summit to the sea along Magela Creek and lower Magela Creek wetlands trap about $90.5 \%$ of the total sediment load input.
\end{abstract}

Key words turbidity; sediment yields; sediment discontinuities; natural sediment traps; sediment budget

\section{INTRODUCTION}

In the Magela Creek basin in tropical northern Australia, sediment yields are low by world standards, except where human disturbance has occurred by mining, burning, and road and house construction (Hart et al., 1982, 1987a; Duggan, 1994; Erskine \& Saynor, 2000). However, the influence of scale on sediment yields in this area has only been investigated by Wasson (1992) and Erskine \& Saynor (2000), and much more reliable data have now been collected. Saynor \& Erskine (2013) mapped ten homogeneous river reaches on Magela Creek from the summit to the sea. Six reaches are located on the highly resistant sandstone of the Arnhem Land Plateau above Magela Falls, and four on the lowlands below Magela Falls. The sand-bedded, island anabranching channel of Nanson et al. (1993) corresponds to Reach 8, the extensive lower Magela wetlands of Finlayson et al. (1989) and Wasson (1992) to Reach 9, and the current estuary, to Reach 10.

The purpose of this study is to determine how suspended sediment and bedload yields vary from the summit to the sea on Magela Creek. We use plot data (up to $900 \mathrm{~m}^{2}$ ) combined with sediment yield data collected at river gauging stations (up to $1570 \mathrm{~km}^{2}$ ) to determine the influence of scale and natural sediment traps (backflow billabongs, channel billabongs, floodplain billabongs, wetlands, floodouts and flood plains) on sediment yields. Magela Creek is located in the World Heritage listed Kakadu National Park which contains Ramsar-listed wetlands of international significance. Furthermore, the Ranger uranium mine and Jabiluka Mineral Lease have been excised from Kakadu National Park to allow mining and processing of uraniferous ore.

\section{METHODS}

We compiled published soil erosion and sediment yield data for the Alligator Rivers Region in the Northern Territory and calculated new suspended sediment and bedload yields for six gauging stations operated by the Supervising Scientist (SS) of the Australian Department of the Environment (Table 1). An automatic pump sampler collected suspended sediment samples at SS gauging stations. A significant relationship between the concentration of silt and clay, and turbidity was 
documented for the three gauging stations (East Tributary, Upper Ngarradj and Swift Creek) at Jabiluka (Moliere et al., 2005), for Magela Creek at G8210009 (Moliere et al., 2008) and for the two stations on Gulungul Creek (Erskine et al., 2014). The relationship between suspended sediment concentration for the silt and clay fraction $(>0.45 \mu \mathrm{m}$ and $<63 \mu \mathrm{m})$ and instantaneous turbidity was highly significant at all SSD stations $(\rho<0.00001)$. Each 5 -minute turbidity reading was converted to silt and clay concentration by the relevant regression equation. The concentrations were then converted to loads by multiplying by mean daily discharge for the 5-minute period and integrating the area under the sedigraph. Mean annual suspended silt and clay loads for SS stations are shown in Table 1. Suspended sand $(>63 \mu \mathrm{m}$ and $<2 \mathrm{~mm}$ ) fraction was also measured for suspended sediment samples (Evans et al., 2004a). The suspended sand fraction of the total suspended sediment load was determined and the suspended silt and clay yield was multiplied by the relevant conversion factor to obtain the suspended sand yield (Erskine et al., 2014). The total suspended sediment yield was the sum of the suspended silt and clay and suspended sand yields (Erskine et al., 2014). An independent check on the accuracy of the method was made by comparing our total suspended sediment yield for Gulungul Downstream (2621 t/year) with that measured by Duggan (1994) for 1984-85, 1985-86 and 1986-87 (2156 t/year). Her measurement period was drier than ours (mean annual rainfall of 1289 versus $1587 \mathrm{~mm} /$ year,) and this accounts for the small difference. Suspended silt and clay is a very small proportion of the total suspended sediment load (Table 1).

Bedload fluxes were measured with Helley-Smith pressure difference samplers at the six SS gauging stations by Erskine et al. $(2011 ; 2014)$ and by Erskine \& Saynor (2014). Roberts (1991) used Helley-Smith samplers to determine bedload ratings for Magela Creek (G8210009) and his suspended sediment and bedload yields are included in Table 1.

\section{EROSION PLOT RESULTS}

Most soil erosion research at Ranger mine has been conducted on waste rock (chlorite schist) from pit 1 and relatively little research has been completed on waste rock (mica schist) from pit 3 . However, characterisation of waste rock from each pit as a single rock type is an oversimplification. We do not review the extensive rainfall simulation results for Ranger mine in this paper.

East et al. (1994) monitored soil erosion under natural rainfall on four unvegetated plots of waste rock from pit 1 for 1987-88 and 1988-89. Two plots had a rectilinear profile on a slope of 1:3, and two plots had a concave profile and slopes of 1:3 above 1:5 above 1:8. One plot in each group was surfaced with $0.3 \mathrm{~m}$ of run-of-mine waste rock and one with chlorite schist. Suspended solids concentrations for all plots varied directly with discharge with highest concentrations coinciding with peak discharge. Suspended solids concentrations varied from $<5 \mathrm{mg} / \mathrm{L}$ to a maximum of $520 \mathrm{mg} / \mathrm{L}$. Concentrations for rectilinear slopes were always higher than for concave slopes because of larger peak discharges. Plots with run-of-mine waste rock had higher suspended solids concentrations than the chlorite schist plots because of more rapid weathering. There was no change in suspended solids concentrations for comparable discharges throughout the wet season because plots were unvegetated. Significant quantities of bedload were discharged from the rectilinear slopes but little bedload was transported from concave slopes. No annual yields were reported.

Riley (1995) used a small flume to compare soil losses from vegetated natural hillslopes with unvegetated batter slopes and cap slopes of waste rock under applied discharges. Maximum sediment concentration recorded was $57000 \mathrm{mg} / \mathrm{L}$ on batters of the waste rock but the natural site yielded a median concentration of only $20 \mathrm{mg} / \mathrm{L}$. Concentrations were commonly high during early stages of a run on waste rock and then decreased as sediment was depleted. Discharge from batter and cap sites had sediment concentrations 10-100 times greater than those from the natural site. Saynor \& Evans (2001) measured suspended load and bedload under natural rainfall from two plots (soil and fire sites) during the 1994-95 wet season and one plot (cap site) during the 1993-94 wet season. The soil site had an average slope of $1.2 \%$ and had been ripped, topsoiled and vegetated eight years previously. The fire plot had an average slope of $2.3 \%$ and was topsoiled, surface ripped and vegetated approximately ten years earlier. The cap site had an average slope of $2.8 \%$, was not surface ripped, had negligible vegetation cover and a fine surface material over a pan. Bedload was 
Table 1 Measured sediment yields in the Alligator Rivers Region.

\begin{tabular}{|c|c|c|c|c|c|c|c|}
\hline Site & $\begin{array}{l}\text { Basin } \\
\text { area } \\
\left(\mathrm{km}^{2}\right)\end{array}$ & $\begin{array}{l}\text { Mean annual } \\
\text { rainfall for } \\
\text { measurement } \\
\text { period } \\
\text { (mm/year) }\end{array}$ & $\begin{array}{l}\text { Mean annual } \\
\text { suspended } \\
\text { silt and clay } \\
\text { yield } \\
\text { (t/year) } \\
\text { (1) }\end{array}$ & $\begin{array}{l}\text { Mean annual } \\
\text { suspended } \\
\text { sand yield } \\
\text { (t/year) } \\
\text { (2) }\end{array}$ & $\begin{array}{l}\text { Mean annual } \\
\text { total } \\
\text { suspended } \\
\text { sediment } \\
\text { yield (t/year) } \\
(1+2)\end{array}$ & $\begin{array}{l}\text { Mean } \\
\text { annual } \\
\text { bedload } \\
\text { yield } \\
\text { (t/year) } \\
(3)\end{array}$ & $\begin{array}{l}\text { Specific } \\
\text { mean annual } \\
\text { total } \\
\text { sediment } \\
\text { load yield } \\
\left(\mathrm{t} / \mathrm{km}^{2} / \text { year }\right) \\
(1+2+3) / A\end{array}$ \\
\hline Koongarra Creek - 1 & 15.4 & 1329 & $\mathrm{~N} / \mathrm{A}$ & $\mathrm{N} / \mathrm{A}$ & 464 & $\mathrm{~N} / \mathrm{A}$ & $\mathrm{N} / \mathrm{A}$ \\
\hline 7J Creek - 1 & 53.5 & 1451 & $\mathrm{~N} / \mathrm{A}$ & N/A & 505 & $\mathrm{~N} / \mathrm{A}$ & $\mathrm{N} / \mathrm{A}$ \\
\hline $\begin{array}{l}\text { Gulungul Creek } \\
\text { Downstream - } 1\end{array}$ & 66 & 1289 & N/A & N/A & 2156 & N/A & N/A \\
\hline $\begin{array}{l}\text { Gulungul Creek } \\
\text { Downstream - 2* }\end{array}$ & 66 & 1587 & 265 & 2621 & 2886 & 1620 & 68.3 \\
\hline $\begin{array}{l}\text { Gulungul Creek } \\
\text { Upstream - } 2^{*}\end{array}$ & 40 & 1611 & 469 & 4639 & 5108 & 1318 & 160.7 \\
\hline $\begin{array}{l}\text { Georgetown Creek } \\
\text { One - } 1\end{array}$ & 7.8 & 1781 & N/A & N/A & 250 & N/A & N/A \\
\hline $\begin{array}{l}\text { Georgetown Creek } \\
\text { Two }-1\end{array}$ & 4.8 & 1044 & N/A & N/A & 30 & N/A & N/A \\
\hline East Tributary $-3 *$ & 8.5 & 1754 & 128 & 486 & 614 & 557 & 137.8 \\
\hline Upper Ngarradj - 3* & 18.8 & 1731 & 207 & 912 & 1119 & 1062 & 116.0 \\
\hline Swift Creek - 3* & 43.6 & 1737 & 148 & 756 & 904 & 1675 & 59.2 \\
\hline Kawudjulah Creek - 4 & 63 & $\mathrm{~N} / \mathrm{A}$ & $\mathrm{N} / \mathrm{A}$ & N/A & 1197 & $\mathrm{~N} / \mathrm{A}$ & $\mathrm{N} / \mathrm{A}$ \\
\hline Ranger Tributary - 1 & 0.22 & N/A & $\mathrm{N} / \mathrm{A}$ & N/A & 195.8 & $\mathrm{~N} / \mathrm{A}$ & $\mathrm{N} / \mathrm{A}$ \\
\hline Jabiru Tributary - 1 & 0.15 & $\mathrm{~N} / \mathrm{A}$ & $\mathrm{N} / \mathrm{A}$ & N/A & 165.2 & $\mathrm{~N} / \mathrm{A}$ & N/A \\
\hline $\begin{array}{l}\text { Magela Creek at } \\
\text { G8210009-5 }\end{array}$ & 600 & 1505.6 & N/A & N/A & 2940 & $\mathrm{~N} / \mathrm{A}$ & N/A \\
\hline $\begin{array}{l}\text { Magela Creek at } \\
\text { G8210009-6 }\end{array}$ & 600 & 1194.7 & N/A & N/A & 2330 & $\mathrm{~N} / \mathrm{A}$ & N/A \\
\hline $\begin{array}{l}\text { Magela Creek at } \\
\text { G8210009-7 }\end{array}$ & 600 & 1560.8 & $\mathrm{~N} / \mathrm{A}$ & N/A & 7080 & 5100 & 20.3 \\
\hline $\begin{array}{l}\text { Magela Creek at } \\
\text { G8210009 - This } \\
\text { paper* }\end{array}$ & 600 & 1812.8 & 4190 & 2095 & 6285 & N/A & 19.0 \\
\hline $\begin{array}{l}\text { Magela Creek at } \\
\text { G8210017-8 }\end{array}$ & 1115 & 1635 & $\mathrm{~N} / \mathrm{A}$ & N/A & 3735 & N/A & $\mathrm{N} / \mathrm{A}$ \\
\hline $\begin{array}{l}\text { Magela Creek at } \\
\text { G8210019-6 }\end{array}$ & 1570 & 1194.7 & $\mathrm{~N} / \mathrm{A}$ & $\mathrm{N} / \mathrm{A}$ & 1700 & $\mathrm{~N} / \mathrm{A}$ & $\mathrm{N} / \mathrm{A}$ \\
\hline $\begin{array}{l}\text { Magela Creek at } \\
\text { G8210019-8 }\end{array}$ & 1570 & 1420 & N/A & N/A & 3611 & N/A & N/A \\
\hline
\end{tabular}

1 From Duggan (1994); 2 From Erskine et al. (2014); 3 From Evans et al. (2004a, b), Saynor et al. (2006); Erskine et al. (2006); Erskine \& Saynor (2014); 4 From Duggan (1988); 5 From Hart et al. (1982); 6 From Hart et al. (1987a,b); 7 From Roberts (1991); 8 From Wasson (1992). * SS

collected after every rainfall event. Bedload was significantly related to total sediment load. Suspended sediment discharge was inversely related to vegetation cover. Bedload declined at a decreasing rate during the wet season for fire and soil sites (vegetated), but increased for cap site (least vegetated) although the slope of the regression line was not significantly different from zero.

Saynor et al. (2012) and Lowry et al. (2014) reported suspended sediment and bedload yields for four $\left(900 \mathrm{~m}^{2}\right)$ plots on a trial rehabilitated landform at Ranger mine constructed largely of mica schist from pit 3 during the 2009 dry season. The purpose of the trial landform was to assess the effects of two types of potential capping material (waste rock and waste rock mixed with $30 \%$ laterite) and two types of planting techniques (direct seeding and tube stock) on suspended sediment and bedload yields. Specific mean annual bedload yield declined exponentially over the first four years since construction (Fig. 1(a)). The highest bedload yield was always generated from plot 2 which had the lowest vegetation cover. Bedload grain size was also dominated by sand then gravel with little silt and clay. Suspended sediment silt and clay yield has only been determined to date for plot 1 for the first four years at $0.0044 \pm 0.0002 \mathrm{t} /$ year $\left(4.9 \mathrm{t} / \mathrm{km}^{2} /\right.$ year $)$. This is less than those for pit 1. 


\section{SEDIMENT YIELD RESULTS}

Analyses of data in Table 1 show that there is no relationship between mean annual suspended sediment yield and both basin area and mean annual rainfall for the Alligator Rivers Region (not reproduced here). The envelope curve of mean annual suspended sediment yield and basin area indicates an inverse relationship (not reproduced here), as also found by Wasson (1992) and Erskine \& Saynor (2000) for a smaller dataset for the same area. For the SS dataset plus Roberts' (1991) data for gauge G8210009 on Magela Creek, mean annual suspended sediment yield exceeds mean annual bedload yield at six of the seven stations, except for Swift Creek. However, mean annual suspended sand yield exceeds mean annual suspended silt and clay yield at five of the six SS stations (Fig. 1(b)). The sole exception is G8210009 on Magela Creek and further work is being conducted at this station to determine a more accurate result. As first concluded by Saynor et al. (2006) for the East Tributary gauge (Table 1) at Jabiluka, sand as suspended sand and bedload is by far the major sediment fraction exported from the Magela Creek catchment upstream of the lower Magela Creek wetlands. All previous results (e.g. Hart et al., 1982, 1987a,b; Wasson, 1992) that exclude bedload, greatly underestimate sediment yields and hence, greatly overemphasise the importance of silt and clay.

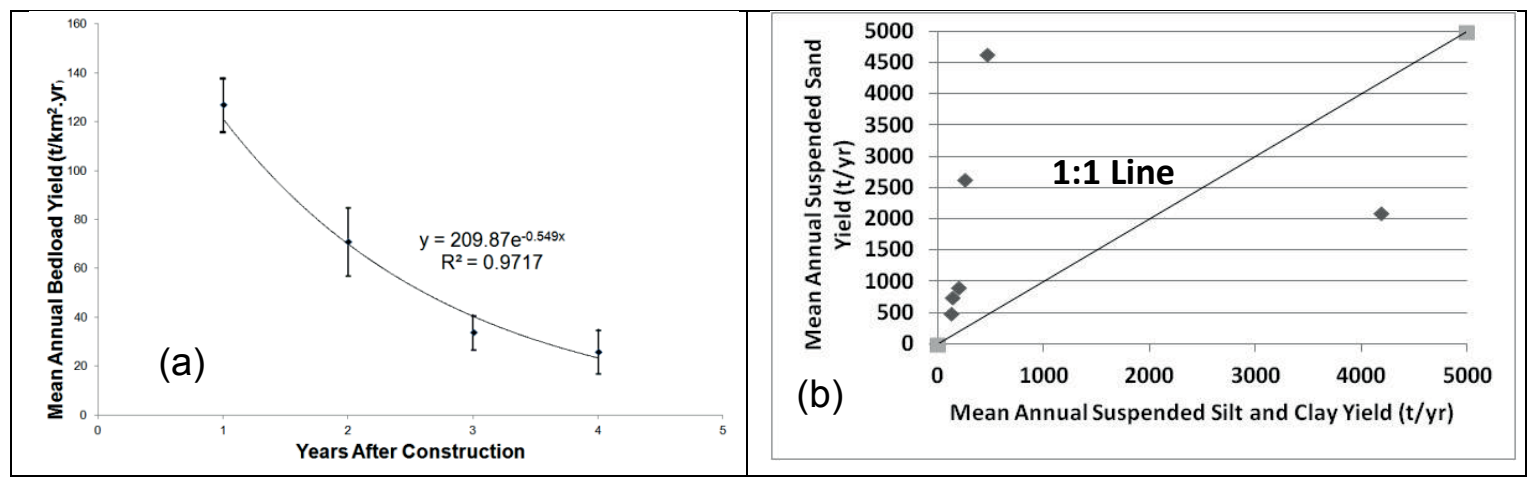

Fig. 1 (a) Changes in mean annual specific bedload yield $\pm \mathrm{SE}$ over time from the four plots on the trial rehabilitated landform. Vertical bars represent SE for four plots for each year. (b) Mean annual suspended sand yield greatly exceeds mean annual suspended silt and clay yield at all SSD stations, except G8210009. Data in Fig. 1(b) taken from Table 1.

\section{LOWER MAGELA CREEK WETLANDS: VEGETATION COMMUNITIES}

Reaches 9 and 10 of Magela Creek (Saynor \& Erskine, 2013) have long been considered a significant sediment trap because of their low elevation, low slope, extensive inundation, dense macrophytes and resultant reduction in flow velocity (Hart et al., 1987b; Wasson, 1992). The distribution and composition of the vegetation communities on the lower Magela Creek wetlands were mapped for 11 May 2010 from multispectral high spatial resolution (2-m pixels) satellite imagery (WorldView2) and a canopy height model derived from an airborne laser scanning survey (Fig. 2). The resultant map (Fig. 2) has 12 vegetation classes consistent with Finlayson et al. (1989). Hymenachne grassland (3639 ha) also occurs with Oryza meridionalis, Nymphaea spp. and Pseudoraphis spinescens (Finlayson et al., 1989). The Melaleuca woodland and Melaleuca open forest typically contain M. cajaputi and M. viridiflora in the northern region and at the edges of the wetland, and $M$. leucadendra in the backswamps (Finlayson et al., 1989). Woodland communities have 10-50\% woody cover (5039 ha), whereas open forest communities have 50-70\% cover ( 822 ha). Oryza meridionalis grassland occupied 4040 ha, P. spinescens grassland, 943 ha, Pseudoraphis/ Hymenachne, 375 ha and Eleocharis dulcis sedgeland, 1054 ha. The invasive weed, Urochloa mutica (Para grass) occupied 2181 ha, and Nelumbo herbland, 243 ha. Salvinia molesta occupied 108 ha and L. hexandra grassland, 967 ha. Mangrove communities (249 ha) are located on Magela Creek estuary (Reach 10). 


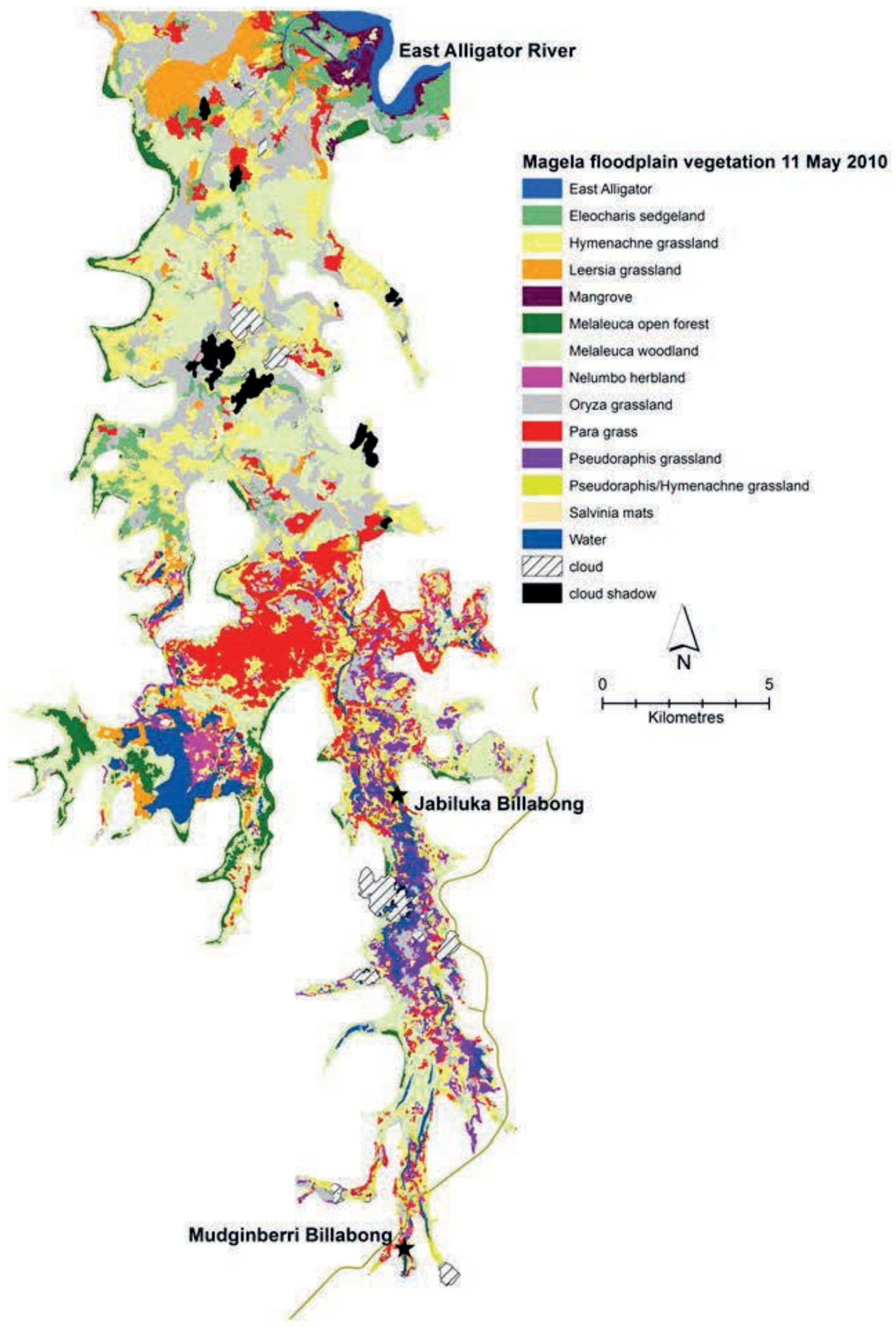

Fig. 2 Vegetation communities of lower Magela Creek wetlands. 


\section{LOWER MAGELA CREEK WETLANDS: SEDIMENT BUDGET}

Hart et al. (1987b) first constructed an approximate sediment budget for lower Magela Creek wetlands which indicated that they were a net sink for suspended solids. They used two approximate methods to determine sediment inflows for just one wet season (1982-83), both of which overestimated sediment inflows because they erroneously assumed that the whole upstream basin uniformly contributed sediment. This assumption is incorrect because upstream flood plains trap sediment, terminal sand floodouts (Tooth, 1999) trap sand bedload (Erskine et al., 2014), and backflow billabongs or terminal wetlands trap and store fine sediment in essentially every tributary valley (Erskine \& Saynor, 2000). Furthermore, Magela Creek derived sediment is completely stored in the upper wetlands (Wasson, 1992).

For the 1982-83 wet season, Hart et al. (1987b) calculated that of the $5400 \pm 5800 \mathrm{t}$ of suspended solids supplied to the wetlands, $1700 \pm 540 \mathrm{t}$ were discharged into the East Alligator River estuary and that $3700 \pm 5900 \mathrm{t}$ were deposited in the wetlands. Based on the mean values, $68.5 \%$ of the supplied sediment would be deposited in the wetlands but based on the maximum values, $85.7 \%$ would be deposited. The exclusion of bedload from these calculations greatly underestimates the sediment trap efficiency of lower Magela wetlands, because no bedload is transported through both reaches 9 and 10 to the East Alligator River. Furthermore, a single water year should not be used for such sediment budget analysis.

Wasson (1992) found that $90 \%$ of Magela Creek sediment load is deposited upstream of Jabiluka Billabong (Fig. 3) in an area of only $30 \mathrm{~km}^{2}$ or $15 \%$ of the wetlands. Channel billabongs are only located in the upper wetlands where there is still a remnant channel, and have well vegetated steep banks, deep (6 m) water and sandy bed (Hart \& McGregor, 1980). Sand is not transported beyond the channel billabongs. Further downstream there are only flood plain billabongs which are reasonably deep (up to $5.3 \mathrm{~m}$ ) with shelving banks and fine-grained bed (Hart \& McGregor, 1980). Wasson (1992) also measured suspended sediment loads at the most downstream station, G8210019, for three years instead of the one by Hart et al. (1987a,b).

The difference in mean annual total sediment load between the two stations on Gulungul Creek in Table 1 for SS data is $2524 \mathrm{t} /$ year. Assuming a soil bulk density of $1.6 \mathrm{t} / \mathrm{m}^{3}$ yields an annual sediment volume addition to the flood plain surface of $4038 \mathrm{~m}^{3} /$ year. This converts to an annual depth of overbank deposition of $4 \mathrm{~mm} /$ year when divided by the flood-plain area between the two gauging stations. The flood-plain area was determined by interpretation of a WorldView-2 image captured on 11 May 2010. Erskine et al. (2014) found that the surface of the Gulungul flood plain was veneered by a variable layer, 5-10 cm thick, of recent overbank deposits of fine-medium sand. This surficial overbank deposit represents the deposition of sediment transported past the Upstream gauge but which is deposited before reaching the Downstream gauge, during the last 34 years since uranium mining commenced at Ranger. This highlights the large potential error of simply measuring a sediment yield at a point on a flood plain river and then uniformly allocating it to the whole basin, as practised by Hart et al. (1987b). Flood plains must be treated as sediment stores in any sediment budget, even in areas of globally low sediment yields.

Erskine et al. (2014) also mapped a terminal floodout (Tooth, 1999) on Gulungul Creek where all the sandy bedload is deposited upstream of the junction with Magela Creek. Gulungul Creek has not supplied sand to Magela Creek, the main stream, for the last 8000 years. In addition, there is a backflow billabong on lower Gulungul at the junction with Magela Creek (Hart \& McGregor, 1980) which exhibits a reverse sandy delta from Magela Creek (Erskine \& Saynor, 2000). Gulungul billabong is floored by deep fine silt and clay with a high organic matter content (Thomas \& Hart, 1984) which indicates that the backflow billabong also has a high sediment trap efficiency for fine suspended sediment (Erskine \& Saynor, 2000). Backflow billabongs were present on all mine site tributaries before mining, and are still present on Gulungul, Coonjimba and Georgetown creeks (Hart \& McGregor, 1980).

Figure 3 shows our sediment budget in terms of total sediment load for lower Magela Creek wetlands for 2003-04 to 2012-13. Wasson's (1992) suspended sediment budget is also shown for comparison. The total sediment load input to the lower Magela Creek wetland is $42000 \mathrm{t} / \mathrm{year}$ and 
the output to the East Alligator River is $4000 \mathrm{t} / \mathrm{year}$. This means that the output is only $9.5 \%$ of the input and that $90.5 \%$ is trapped and stored in the wetland. Our error terms are standard errors and reflect the total supply of clastic sediment, not just suspended sediment as previously reported by Hart et al. (1987a,b) and Wasson (1992). As suspended silt and clay constitute a minor component of total sediment load, suspended sediment only should not be used for such a budget. Sand is not transported very far into the wetlands, changing the character of billabongs from channel billabongs upstream to flood plain billabongs downstream.

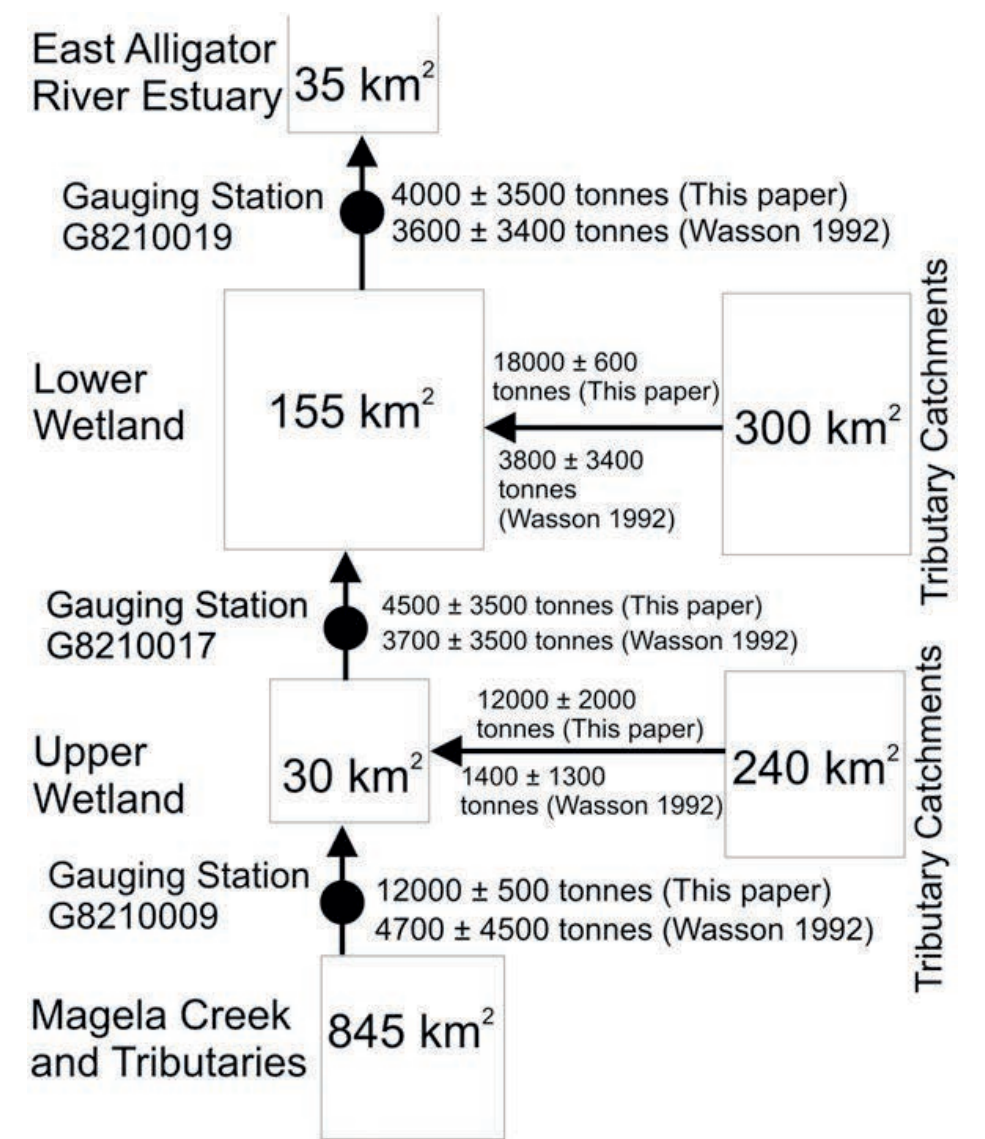

Fig. 3 Mean annual sediment fluxes for lower Magela Creek wetlands. Wasson (1992) only cites suspended sediment load and this paper uses total sediment load for the period 2003-04 to 2012-13.

\section{CONCLUSIONS}

The short answer to the question posed in the title of this paper is no for both suspended sediment and bedload. Very little silt and clay is generated from the tropical Magela Creek drainage basin. While sand production is much greater than silt and clay, sand is not transported by many tributaries into Magela Creek (Nanson et al. 1993; Erskine et al. 2014). However, soil erosion rates on the rehabilitated Ranger mine, where waste rock from pit 1 is used for a surface cover, may greatly increase sediment yields. In addition to the low natural sediment generation rates, many efficient sediment traps store sediment throughout the channel network. These sediment traps comprise extensive backswamps on meandering channels, flood plains on anabranching channels, floodouts, backflow billabongs on tributaries immediately upstream of the junction with higher order channels and the $220 \mathrm{~km}^{2}$ lower Magela Creek wetlands. Lower Magela Creek wetlands trapped about $90.5 \%$ of the inflowing total sediment load for the period 2003-04 to 2012-13. 


\section{REFERENCES}

Duggan, K. (1988) Mining and erosion in the Alligator River Region of northern Australia. PhD Thesis, School of Earth Sciences, Macquarie University, New Zealand.

Duggan, K. (1994) Erosion and sediment yields in the Kakadu region of northern Australia. In: Variability in Stream Erosion and Sediment Transport (ed. by L. J. Olive, R. J. Loughran \& J. A. Kesby), 373-383, IAHS Publ. 224, IAHS Press, Wallingford, UK.

East, T. J., et al. (1994) Erosional stability of rehabilitated uranium mine structures incorporating natural landform characteristics, northern tropical Australia. Z. Geomorph. 38, 283-298.

Erskine, W. D. \& Saynor, M. J. (2000) Assessment of the off-site geomorphic impacts of uranium mining on Magela Creek, Northern Territory, Australia. Supervising Scientist Report 156, Supervising Scientist, Darwin NT.

Erskine, W. D. \& Saynor, M. J. (2014) Bedload yields for sand-bed streams in the Ngarradj Creek catchment, Northern Territory, Australia. Hydrol. Processes, in press.

Erskine, W. D., et al. (2011) Bedload transport, hydrology and river hydraulics in the Ngarradj Creek catchment, Jabiluka, Northern Territory, Australia. Supervising Scientist Report 199, Supervising Scientist, Darwin NT.

Erskine, W. D., et al. (2006) Bedload transport, yield and grain size in a seasonal tropical river in northern Australia. $30^{\text {th }}$ Hydrology and Water Resources Symposium, 4-7 December 2006, Launcestion, Tasmania, Institution of Engineers Australia, Barton.

Erskine, W. D., et al. (2014) Geomorphic characteristics of the Gulungul Creek catchment. In: eriss Annual Research Summary 2012-2013. (ed. by R. van Dam). Supervising Scientist Report 205, Supervising Scientist, Darwin NT, 99-116.

Evans, K. G., et al. (2004a) Baseline suspended-sediment, solute, EC and turbidity characteristics for the Ngarradj catchment, Northern Territory, and the impact of mine construction. Supervising Scientist Report 179, Supervising Scientist, Darwin NT.

Evans, K. G., et al. (2004b) Erosion risk assessment of the Jabiluka mine site, Northern Territory, Australia. J. Hydrol. Eng. 9, 512-522.

Finlayson, C. M, Bailey B. J. \& Cowie, I. D. (1989) Macrophyte vegetation of the Magela Creek flood plain, Alligator Rivers Region, Northern Territory. Research Report 5, Office of the Supervising Scientist, Canberra.

Hart, B. T., Davies, S. H. R. \& Thomas, P.A. (1982) Transport of iron, manganese, cadmium, copper and zinc by Magela Creek, Northern Territory, Australia. Water Res. 16, 605-612.

Hart, B. T. \& McGregor, R. J. (1980) Limnological survey of eight billabongs in the Magela Creek catchment, Northern Territory. Aust. J. Mar. Freshw. Res. 31, 611-626.

Hart, B. T., Ottaway, E. M. \& Noller, B. N. (1987a) Magela Creek system, northern Australia. I 1982-83 Wet-season water quality. Aust. J. Mar. Freshw. Res. 38, 261-288.

Hart, B. T., Ottaway, E. M. \& Noller, B. N. (1987b) Magela Creek system, northern Australia. II Material budget for the floodplain. Aust. J. Mar. Freshw. Res. 38, 861-876.

Lowry, J., et al. (2014) A multiyear assessment of landform evolution model predictions for a trial rehabilitated landform. Lifeof-Mine Conference, Brisbane, Qld, 10-12 July 2014, The Australian Institute of Mining and Metallurgy, Carlton, in press.

Moliere, D. R., Saynor, M. J. \& Evans, K. G. (2005) Suspended sediment concentration-turbidity relationships for Ngarradj - a seasonal stream in the wet-dry tropics. Aust. J. Water Res. 9, 37-47.

Moliere, D., Evans, K. G. \& Turner, K. (2008) Assessment of continuous Magela Creek turbidity data upstream and downstream of Ranger. In: eriss Annual Research Summary 2006-2007 (ed. by D. R. Jones, C. Humphrey, R. van Dam \& A. Webb) Supervising Scientist Report 196, Supervising Scientist, Darwin NT, 124-130.

Nanson, G. C., East, T. J. \& Roberts, R. G. (1993) Quaternary stratigraphy, geochronology and evolution of the Magela Creek catchment in the monsoon tropics of northern Australia. Sed. Geol. 83, 277-302.

Riley, S. J. (1995) Aspects of the difference in the erodibility of the waste rock dump and natural surfaces, Ranger Uranium Mine, Northern Territory, Australia. Applied Geography 15, 309-323.

Roberts, R. G. (1991) Sediment budgets and Quaternary history of the Magela catchment, tropical northern Australia. PhD Thesis, Dept. of Geography, University of Wollongong, Australia.

Saynor, M. J. \& Erskine, W. D. (2013) Classification of river reaches on the little disturbed East Alligator River, Northern Australia. International Journal of Geosciences 4, 53-65.

Saynor, M. J., et al. (2006) Water, solute and sediment yields for a seasonal tropical river in northern Australia. $30^{\text {th }}$ Hydrology and Water Resources Symposium, 4-7 December 2006, Launcestion, Tasmania, Institution of Engineers Australia, Barton.

Saynor, M. J. \& Evans, K. G. (2001) Sediment loss from a waste rock dump, ERA Ranger Mine, Northern Australia. Aust. Geog. Stud. 39, 34-51.

Saynor, M. J., et al. (2012) Assessing erosion and run-off performance of a trial rehabilitated mining landform. Life-of-Mine Conference, Brisbane, Qld, 10-12 July 2012, The Australian Institute of Mining and Metallurgy Publication Series No. 6/2012, Carlton, 123-132.

Thomas, P. A. \& Hart, B. T. (1984) Textural characteristics and heavy metal concentrations in billabong sediments from the Magela Creek system, northern Australia. Technical Memorandum 9, Supervising Scientist for the Alligator Rivers Region, AGPS, Canberra.

Tooth, S. (1999) Floodouts in central Australia. In: Varieties of Fluvial Forms (ed. by A. J. Miller \& A. Gupta), 219-247. John Wiley \& Sons, Chichester, UK

Wasson, R. J, (ed) (1992) Modern sedimentation and late Quaternary evolution of the Magela Creek plain. Research Report 6 , Supervising Scientist for the Alligator Rivers Region, AGPS, Canberra. 